\title{
Representing Nevis: an approach to reconfiguring the Caribbean heritage sites as cultural space
}

\author{
M. K. Uslick \\ USA
}

\begin{abstract}
In an attempt to understand the intricacies of the identity of the Caribbean state, this paper has investigated how attitudes toward colonial history, post-colonial theories and architectural regionalism have affected the contemporary condition of architecture on the island of Nevis. Nevis is a small island, only 36 square miles of volcanic land that lies 200 miles south of Puerto Rico. Its society was born of an act of colonization; its identity formed by the sugar plantation system. The people have emerged from a history of violence and subjugation, slavery and cultural oppression. Their acts of resistance and creation contributed to history and their lives have intersected to create a new culture and identity. Architecture can represent the people of Nevis because the journey of this population cannot be reduced to merely words in books or in archives. It deserves visual and active demonstration so that everyone can participate in the experience of the culture as it stands today. This paper proposes an addition to the existing museums and heritage sites of Nevis, which are Euro-centrically structured. Theories of tropicality and regionalism will contribute to the design of a new museum, and the concept for an eco-museum as a holistic interpretation of heritage will be applied to interventions within five of the heritage sites that now lie in ruin. Nevis needs a culturally distinctive island identity to compete in the tourism industry. Using architectural intervention as a part of the museum program, it can cultivate this distinction while it also continues to maintain the structures from ruin.

Keywords: heritage tourism, heritage architecture, architectural intervention, Caribbean, Nevis, regionalism, cultural heritage, eco-museum, culture and history, sugar plantation.
\end{abstract}




\section{Introduction}

The objective of this proposal is to explore local identity and culture and their influence and relationship to existing and future architecture on the island of Nevis, West Indies. In an attempt to understand the inherent intricacies of identity in the present Caribbean state, an appraisal of theories, terms, and ideas will be used as a basis and a method to investigate how architecture can be a means of representation for the people in this Caribbean region. This representation will challenge the approach of the existing museums within Nevis. It will then question the implications and possible applications of whether its heritage sites should be used as part of this representation and as a means to build the economy through heritage tourism. It will be structured providing a three pronged inquiry into how attitudes toward colonial history, postcolonial theory, and architectural regionalism can affect the contemporary state of architecture on Nevis. The outcome will culminate with design solutions for representation of heritage and culture in the current social and economic setting, focusing this depiction through the typology of a museum.

The first prong will attempt to reveal the current situation regarding the identity of the Caribbean island and question whether it is symptomatic of its past. While changes in society are ongoing and inevitable, architecture becomes a manifestation and a legacy of its culture; the most tangible evidence of it. Therefore a look into the effects of colonization that have continued to persist through to the postcolonial era can provide evidence of conditions which can inform a better understanding of the relationship between the islands architecture and its identity and culture today.

\subsection{History}

The current local culture of Nevis is an inadvertent consequence of the fusion of various cultures which were driven together by the exploitive methods of the early European colonists, as the region was acquired and developed purely as a tool for the production of wealth for Europe. The island society belonged to a small few, who regarded the bulk of the population, the black slaves, as non-persons outside the social ranks of civilization. Due to this marginalization of the black population, Afro-Caribbean culture has not revolved around the establishment of an autonomous, distinct sociocultural system, but has emerged out of the components of an Afro-Caribbean context of life within an oppressive colonial system. The introduction of indentured laborers from India and China has added to the hybrid population that exists today.

Nevis lies near the top of the Lesser Antilles archipelago, about 200 miles south of Puerto Rico, and just west of Antigua. This small island's history has been filled with violence, wealth and poverty, adversity and triumph over adversity. First inhabited by the indigenous Arawak Indians, the volcanic island was named San Martin by the Italian explorer Christopher Columbus. By 1540 the island's name appeared on maps as "Nieves", in Spanish meaning snow. 
The English took possession of the island in 1628, in which the environment unquestionably produced the setting for the culture to propagate. It was discovered that the rich volcanic soil produced the best sugar in the West Indies. Nevis became the leading sugar provider in the Leeward Islands and therefore, the wealthiest. It became a colony where the sugar economy was to shape the social organization that would last for centuries.

The contemporary culture and society in the Caribbean has emerged from this colonial invasion which involved the decimation of the aboriginal population. As a result, the area today displays no heirs of former tribal natives, as does most of the Third World, but is populated by descendants of those who were brought there to labor in plantation systems centered on slavery and indentured labor. In the Caribbean, rural communities therefore have a long history of modernization and integration into the western world system and are not the sources of distinct cultural tradition and continuity.

\section{Post colonialism: the effects of colonization}

"Postcolonial is a word possessed of as many meanings as there are theorists to define it, and the concerns it addresses would surely exist whether the word did or did not. Finally then, post-colonial is, like any other theoretical category, is a useful tool for evaluation, a tool made the more useful when used in conjunction with, and opposition to, the multitude of other contextual frameworks available for the understanding of culture- one of many, and all of value" - Michel Foucault. We can see from this quotation that postcolonial theory is a diverse subject, in which a lot of other discourses can be applied. It looks at experiences and backgrounds of many different groups and dialogues. But to understand post colonialism, it must be put into context. It is then initially significant to understand colonialism and some of its main points of contention. The Oxford English Dictionary defines colonialism as: A settlement in a new country... a body of people who settle in a new locality, forming a community subject to or connected with their parent state; the community so formed, consisting of the original settles and their descendants and successors, as long as the connection with the parent state is kept up [1].

This definition inadvertently reveals one of the key matters outlining the theory of post colonialism; it avoids any mention or reference to anyone other than the colonizers themselves. There is no mention of the conquest of other peoples land; no mention of appropriation, exploitation, or subjugation of resources and people. What if, in the process of forming this settlement in the new land meant unforming or re-forming the communities that existed there already: And what if this settlement captured and brutally shipped Africans to plantations and towns as slaves [2]? Would colonization be defined differently? This definition speaks to why the colonizers of Europe may have been able to distinguish themselves from all of the 'other' people that they suppressed.

Postcolonial theory is built in large part around this concept of otherness. In 1978, Said published his Orientalism, a work that builds on Foucault's insights and that has become the reference work for postcolonial studies. Said focuses on 
the binary opposition of Us vs. Them. He places his example as the Orient vs. Occident, or simply put, East vs. West, which can also be thought of as North vs. South, in the case of the tropics. He shows that scholars in the west failed to accurately describe the people, the environment, and the culture of the Orient. Instead of describing them with impartiality and accuracy, the western people, instead prescribed the qualities that the west would prefer to the Orient.

They actually created the Orient, which does not exist in reality, to serve in western imaginary as that colonized 'other'. In fact, Said states in his critique, "My whole point about this system is not that it is a misrepresentation of some Oriental essence - in which I do not for a moment believe - but that it operates as representations usually do, for a purpose, according to a tendency, in a specific historical, intellectual, and even economic setting." [3]. Therefore, by giving the people in the Orient qualities that were considered inferior, the westerners could define themselves as superior. These tensions of power and the subjectivity of the 'others' have become central to the colonial discourse, and the consequences of this power and subjectivity that still resonate today have become central to postcolonial discourse [2].

The current local culture of Nevis is an inadvertent consequence of the fusion of various cultures which were driven together by the exploitive methods of the early European colonists. These cultural contexts of life developed primarily within contained specified zones left for the black population within the plantation society. Therefore their cultural development and display depended on the colonial society [2]. In Black Skin, White Masks, Fanon defines colonized people as not simply those whose labor has been appropriated, but those "in whose soul an inferiority complex has been created by the death and burial of its local cultural originality" [4].

In addition to the Europeans and the African slave labor, the introduction of indentured laborers from India and China has added to the hybrid population that exists today. Consequently, Nevis cultural identity has a history of complexity involving the continuous founding, evolution and assertion of culture within multiple frameworks rather than a model of self-contained, cultural entities [5].

Another issue that is critical to the definition of postcolonial concerns the prefix 'post' which can signify different meanings. The post can imply an 'after' as in temporal circumstances or as in an ideological sense as in 'supplanting'. "It is the second implication which critics of the term have found most contestable; if the inequities of colonial rule have not been erased, it is perhaps premature to proclaim the demise of colonization" [2]. This philosophy is not one that allocates changing the past, but one that should bring awareness to the present realities, which are the consequences of the past. These consequences allow for social and economic exploitation in post-independent nations, which can directly relate to the groups identity. The past becomes part of the modern society as the plantation great houses, the sugar mills and churches built during the colonial reign are visible and powerful daily reminders of the English dominant rulers that once controlled the island. These are the circumstances that influence the island today that allows us to assimilate "the history of anticolonial resistance with contemporary resistances to imperialism and to dominate western culture" [2]. 
The ultimate goal of post-colonialism would be to reduce the lingering effects of colonialism on cultures, although the theory merely defines the problem. It is not necessarily concerned with reclaiming the past, but it doesn't seem to lay the foundation of how the previously colonized world can move beyond the time of subjugation. In fact it seems to linger in the trauma of colonization, and utopian ideals are not going to solve the problem. One of the questions that it poses is when does a nation cease to be oppressed and become a wealth of cultural diversities of a post-colonial setting? How can they utilize this setting (the heritage sites) in an effort to move beyond the challenges of the postcolonial era and express the diversity of the population without perilously plunging into a state of neocolonialism, which might be disguised as heritage tourism today?

Relevant to the current conditions on the island of Nevis, the value of the heritage sites lies latent. In order for the Nevisians to revitalize their architectural heritage and to uncover their multi-cultural identity and independence, a return to regionalism is in order; a regionalism not in the critical sense, or in a return to the indigenous, but a regionalism that is active and proactive. Furthermore because the privilege of one historical ethnographic account is presently being emphasized over others in its representation, an active regionalism would provide an establishment for a more comprehensive depiction of its hybrid culture.

The second prong of this investigation outlines the tension between the critical theories of post colonialism and critical regionalism (which only seem to state the problems) vs. ideas of an active and proactive regionalism along with an understanding of tropicality (which can lead to solutions to the problems). Establishing an approach for the present day, an active regionalism would be based in patterns of activities. This type of regionalism can provide a foundation for how to think constructively the difficulties between architectural conservation and intervention regarding the heritage sites.

\section{Critical regionalism is, at heart, a postcolonial concept [6]}

Concurrent with the ideas of post colonialism, critical regionalism tends to get caught up in opposition in the search for identity as well, but doesn't seem to offer up a solution. In Eggener's, A Critique of Critical Regionalism, he sees this as a kind of stand-off, and says Frampton's version of critical regionalism revolves around a central paradox, a binary opposition: "how to become modern and return to sources; how to revive an old dormant civilization and take part in universal civilization". It is the tension arising from this problem - the struggle to resolve it more than its eventual resolution - that fuels critical regional discourse [6]. As architectural historian Anthony King has warned, "These global theories... enable those who produce or adopt them to view the world of 'others' from one particular place, from one point of authority, from one particular social and cultural position. They produce a totalizing vision or overview which is likely to be at odds with the meanings which the inhabitants place on the buildings themselves. We need to be sure that we're not creating a new intellectual imperialism" [6].

Hamilton Harris wrote that regionalism "is a state of mind" [7]. By attending more directly to these states of mind, by heeding the voices of those responsible 
for building a particular culture, architects among many others, rather than imposing formulas upon them, might come to understand better the richness of internal, local discourses in their full range and complexity [6]. Much like the ideas of post-colonialism, the response of the architectural theories of critical regionalism is preoccupied with resistance. This resistance is in response to modernist architecture, which could be compared to the relationship of the postcolonial to the colonial. As an alternative to the resistance of critical regionalism, the active regionalism proposed would be based upon present-day patterns of activities and needs of a cultural group of people. It would take place within the context of cultural surroundings. To consider the views of Cassidy, his essay Becoming Regional over Time: Toward a Reflexive Regionalism, he notes that "The world view posited by Tzonis, Lefaivre and Frampton, (the most recognized advocates of critical regionalism) assumes that no authentic cultural practices still exist. It is assumed that everything contemporary society desires and produces have been influenced by what (Theodor) Adorno (sociological philosopher) describes as the "culture industry" [8]. If the definition of authentic cultural practices were defined as practices made by a homogeneous indigenous peoples, they may no longer exist, but any type of cultural practices that are based in activities of a society, regardless of the origins of its people could be considered authentic. If regionalism is a state of mind in which the culture can reflect this state of mind through what they do, it is a very real circumstance, and therefore authentic. As Cassidy points out, the above theorists' ideas "discount all regional manifestations that celebrate traditional notions of regional identity. It does not recognize the collective experience of a particular landscape - the sense of regional place" [8]. Cassidy states that he realizes that he cannot design buildings that are in themselves regional, but can only design buildings that have the capacity to be inhabited with regional and local practices. He believes that this would make these buildings become architecturally regional over time.

This could be expanded one step further to say that human practices give meaning to the built form, which in turn allows the building to derive its meaning from the activities that take place there. This meaning is the essence of the state of mind of the culture, its identity, which makes it regional at its inception.

\section{Tropicality: a different perspective}

Architect, Stagno has formed ideas on tropical thinking with a theory called tropicality. This theory specifically inspires the Caribbean state of mind because tropicality is embedded within the daily activities of the place. He states that immersion into the tropical world is the way in order to understand this phenomenon. Upon his own immersion, Stagno states that his own Cartesian methods and ways of thinking were being challenged, and he began to realize that there were other forms of thought that could enrich the understanding of an attitude "which privileged humanist values in relationship, predominated, as a definite approach in the decision-making process, and so outweighed the reasoned approach" [9]. He explains that the atmosphere itself infiltrates and influences reasoning within the tropics, and maintains the thought that the dominant culture 
invasion only partially effected the colonized by their incoming mode of thought. Stagno states that in order to understand tropicality it is appropriate to think as the writer Edouard Glissant says, "In the poetics of relationships, more than in poetics of being". This allows us to claim that in the tropics, man exists in proportion to his integration with a place (I am here, therefore I am); that challenges the principle of "I think, therefore I am" [9]. This quality is one of the most defining characteristics of tropicality, since it perceives life in relation to its environment. This way of thought is a determining feature of the people from the tropics, which may constitute an analysis in moving past colonization and defining the fluidity of the culture expressed today. This way of thought would permit an active regionalism to be established.

\section{The heritage sites, tourism and the museums of Nevis}

The third prong of this investigation explores heritage tourism and ideas for the museum as representation. Many of the heritage sites of Nevis lay untouched today, with some lying in ruin, taken back by nature. The Nevis Conservation and Historical Society designated over thirty architectural locations on their 'heritage map'. The society will soon become a trust, acquiring the responsibility of guardianship to the sites. This poses questions of conservation vs. intervention, as the trust will be obliged to develop an approach to maintain the historic fabric, cultural context, physical characteristics as well as the potential revenue that can be created from these sources.

The World Tourism Organization has defined heritage tourism as "an immersion in the natural history, human heritage, arts, philosophy and institutions in another region or country" [10]. In Nevis, cultural tourism has been identified and pointed as a future growth industry, especially in the current economic condition as few other opportunities for development seem existent [11]. Yet the tourism industry should not be allowed to drive a cultural industry. In his essay "Heritage Tourism and the Myth of Caribbean Culture", Nettleford observes: Cultural tourism to many people is, in any case, a camouflage for "touristic culture" which any West Indian who is serious about his heritage and the integrity of its authenticity and autonomy would not wish to adopt. And understandably so! For where cultural tourism works best is when it is very much in place, active alive and available in the normal circumstances for their guests (the visitors) to come and enjoy... people (should) never dig out their heritage for someone else, least of all for tourists. Dig it out for themselves first and then invite guests to come in and enjoy it with them [12].

This idea also supports the basis for an active regionalism. One of the assumptions in the creation of the cultural 'other' throughout colonialism was that the 'other' did not travel, and therefore didn't experience any type of cultural exchange that tourism creates. This superiority functioned as a way of subordinating 'other' histories, ideas and cultures, which maintained the hegemony of European culture. Currently, the idea that an under-developed region such as Nevis is in some way 'natural' in its resistance to globalization, provides the necessary 'other' as the 'object' of tourism today. African Caribbean culture 
has been diasporic since its inception, and should be valued in its history. It is imperative for the region to be active in their culture and proactive for themselves, as well as to exhibit the full extent of their cultural history, as a confirmation of their survival. It is this type of attitude that should be adopted and representative of the people when accepting visitors, such as tourists who will share in cultural activities.

Cummins has written works giving a thorough history of the trials and tribulations of museums within the Caribbean. This information is valuable in understanding the struggles of the colonized in their attempt to reposition themselves as subjects of exhibition within cultural tourism, to representing themselves in an exhibition. The first museums within the Caribbean were principally regarded as a means of informing visitors of the resources of the colonies and the benefits of investment into the local industry. This was justified as a way to enhance national identity. "The inclusion of anthropological collections lent credence to this claim." As Cummins notes, "The assimilation of African and Amerindian cultural heritage as part of the exotic baggage of a territorial prize, was, in fact, the continuation of an insidious process of separation and eventual disinheritance which was to plague the majority of the West Indians for decades" [13]. The Caribbean Tourism Association developed in the mid twentieth century brought sympathetic support for the restoration of historic sites, but unsurprisingly, the major focus was on the European great houses and official buildings, omitting any references to Afro-Caribbean vernacular. The result was a predictable distinct Euro centric bias that gave little recognition to more authentic Caribbean building [13].

Nevis is currently working towards fostering its regional identity, only gaining full independence in 1983. Contemporary architectural intervention can distinguish the strategies of the 'survival' of the people, rather than their resistance to change. Museum development within the region is now being adopted by local individuals and historical societies, but still lacks diverse cultural context. Currently, within the small island of Nevis, there are two museums, funded and operated by the local community, grants and the Nevis Conservation and Historical Society. The Horatio Nelson Museum provides an account of the history and life of the British naval officer it is named for. The Society itself notes that the museum "sets the stage for Nelson's many glorious accomplishments by briefly telling the story of Nevis' history - Amerindian, European dominance, slavery and sugar" [14]. In other words, within the spotlight stands the European British naval officer. The history of Nevis the stage, diminished in importance, within the backdrop of a great British man. The second museum, the birthplace of Alexander Hamilton, therefore named for the US Secretary of the Treasury, provides a small, but improved overview of history of the island. Unfortunately, it delivers a less than interesting experience for visitors, and much of the islands population are not even aware of its existence. By ignoring the relevance of the non-European Caribbean experience, it most likely alienates the majority of the populace.

An article written by Cannizo, "How Sweet It Is: Cultural Politics in Barbados" examines the role of the museum as "symbolic structures which make visible our public myths". Her exploration of the Barbados Museum's redefining of local 
culture, reflects that "By not displaying the cultural heritage of the majority of the population, the museum has taken from them, by implication their role as history makers, as active participants of their own past" [15].

\section{Looking forward}

With an effort to establish an active and proactive regionalism, the Nevis museums can move forward and beyond the displays of the "public myths", making visible what was once a hidden past. It should provide a means to represent culture through architecture in the contemporary Caribbean society. In an effort to represent a community, a virtue should be made of diversity, and we must resist temptation of romanticizing one cultural epoch over any other. Ethnographic representation through architectural practice should identify the cultural palimpsest as a witness of life; past, present and future. Based on history, relevant theory and an understanding of tropicality, architects can develop arguments for possible contemporary practices within this diverse region. It should be allowed to depend largely on current local traditions, needs and initiatives within the life of the community. This unique form of active cultural contribution within a museum will likely be effective and most readily understood, accepted, and valued locally as a center for activity, identification and tourism proceeds.

\section{Project premise}

The project 5 will represent a small system of heritage sites comprising a correlation to the larger heritage system of 30 sites that exist on the island. Within this framework, the intent is to stimulate the role of architecture at each site as a place of new discovery, exhibition and living culture. The +1 project reconfigures the role and function of the museum. It can now be conceived as a cultural space where experimentation can be developed and new strategies of representation deployed. It will adapt and evolve as responsive architecture.

The basic eco-museum necklace model has been utilized and expanded upon for the project $5+1$. The project 5 heritage sites become the beads of the necklace as a heritage trail for the visitor to explore. The difference from the basic model is that the +1 museum now becomes the clasp of the necklace. It becomes the beginning and the end of the journey and is regarded as the thread of the necklace. It not only links the sites together through participation, but it reveals the missing link of the non-tangible part of Nevis culture.

The project +1 seeks to empower the local people. It will create space to represent the past, to remember and reflect; it will move through post-colonialism by creating space that allows for reinterpretation and building of new cultural identities; it will remember that heritage has to do with remembrance of the past in the present, and it will engage the community through public programs and activities. By ways of memory, experience and participation the museum will provide areas of reflection and areas of gathering through time and space. 


\subsection{Cultural museum}

The journey begins in the project +1 complex as an individual reflection and learning experience. The complex itself is a microcosm of the island experience, preparing the visitor and community for the larger heritage trail.

The goal of the complex will allow the citizens to actively participate in presenting their heritage, thus allowing their guests to participate authentically in the experience; given that the more we are able to participate, the more authentic will be the connection. Since this is determined by the degree to which one has access to the possibility of real local experiences interwoven with the local history, the museum will be reinterpreted as cultural space through the participation and sponsorship of the undertakings by its citizens.

The architecture would incorporate 'memory', as the eastern wall would represent the lost lives of the ancestors who first came to Nevis by way of the triangular trade route. Daylight would infiltrate the main exhibition room through triangular 'windows' casting different shadows through-out the day as a subtle reminder of the evolution of time, and as the shadows diminish in size and amount we are prompted to recall their passing. As the visitor nears the end of the heritage journey he will be invited to return to the project +1 complex to participate in the preservation of the non-material heritage. The community will engage their guests in a gathering with activities and events' celebrating the society as it exists today, making visible the intangible and hidden parts of the culture of the people of Nevis. By participation we gain an experiential depth that builds a connectedness to the life and how it is lived within a place. Only then can we respond to history by recognizing the contemporary culture. We can respect the past, and look to the future by living and experiencing the present.

\subsection{Heritage intervention}

Continuing on to the heritage trail, the visitor will experience the project 5 interventions. The project 5 seeks to explore the possibilities of interaction within the ruins as physical documentation of the transformative process, providing evidence of origin, lineage and inheritance. The architectural interventions take advantage of the nature of the transformation and the history of the sites to inform their creation and the interaction with not just the existing condition, but a future one, while remaining respectful of its past. These heritage sites also have a range in which the visitor will participate in the experience either individually, reflecting on the meanings and the history, or collectively as a gathering place to learn.

Intervention \#1 will be located at the mill in New River, which was the last sugar mill used on the island. Many residents remember it as operational. The history of this heritage site is recent in comparison to the others. The site retains many of the functional parts of the mill and should be educational. This possibility makes it relevant for the intervention to be used as a museum. The existing mill ruins will be sheltered with a contemporary primitive hut in which light will penetrate, and water will be channeled into nearby cisterns. It will provide a safe and functional catwalk viewing area above the machinery and buildings. A map 
of the mill plan and all of its previous functions will be available along with a time line of the history of the sugar process in evolution.

Intervention \#2 will be located at the Nevis Fort which was built by slave labor in 1671. Nevis was the wealthiest island in the Leeward Islands and at that time, the fort mounted 26 cannons. The wealth of the island remained the prime target of the French and in 1706 they attacked the island. Once the fort fell, the militia moved into Charlestown and burned the city. They captured 3000 slaves and took them from the island. This intervention will pay tribute to the fallen fort and the slaves who not only built the fort, but who established a defensive against the French during the attack. It pays tribute to the 3000 that were taken. Presently, the cannons lie around the perimeter of the site corroding and the main building itself is in ruin. The intervention will reconstruct the shape of the building but will be placed within the perimeter of the ruined walls. An opening will allow the visitor to enter the interior to experience the infiltration of light through 3000 holes that represent the slaves. A trench will surround the fort and the cistern and extend out to each of the cannons where they are placed. The society intends to restore the cannons and they will be removed from the site. While they are gone, the intervention will call for a platform in which a mold of each cannon and its number will be recorded for the replacement in the future.

Intervention \#3 will be located at Cottle Church which a most important site to the people of Nevis as it was the first church built that would allow everyone on the island to worship together regardless of skin color and social status. The intervention proposed will cover what is remaining of the original church structure and protect the walls below. The canopy which will look as if it has grown from the land will supply shelter and house PV panels that will bestow a glowing light above the church at night. The interior will be planted wall to wall with flowers.

Intervention \#4 will be located near the baobab tree which lies at the entrance of the Montravers Estate Plantation. The only one of its kind on the island, this tree is hundreds of years old and was brought to the island from Africa. The tree is said to be a symbol of life and is a public meeting place within the African community. The circle is known as a social geometry. Within this plantation the slave quarters were placed within a circular pattern which formed their small community within the colonial plantation society. Areas such as these are where the Afro-Caribbean culture originated, building their society and sense of connectedness. The intervention is simple but meaningful in its combining of the circular geometry of the community and the meeting place beneath the baobab tree. The foundation of the pathway leading to this site will rise from the ground plane into an elevated seating area which will circumvent the tree. It sits on its own roots created beneath the sitting area.

The final intervention \#5 will be located at the sugar mill windmill at Coconut Walk. The windmill has become an iconic symbol of the Caribbean and is often misrepresented and romanticized within the architecture of the hotel industry and private ownership. Sugar has shaped the environment and the cultural heritage of this Caribbean island for 350 years. All of the arable land was separated into plantations for sugar production. The windmill was used for its wind power to crush the cane. The labor was intensive and the slaves worked more than 20 hours 
a day without rest and little food. As a form of communication and a way to assert their own culture into the life of the colonial plantation the slaves would sing in their own language in the fields during the harvest. This heritage site carries with it much emotion for the island. For this reason the intervention will respect the architecture and not intrude into it. But will surround it where the cane had been grown. What is important is the atmosphere of the original sugar mill that was built on this site. The intervention celebrates song and communication of the AfroCaribbean performance culture as an installation of art. The art represents the sugar cane within the fields blowing in the wind, and it will produce sound as a wind chime expressing the voices of the slaves that once worked the land. The chimes will lead the visitor on a path from the mill to the Atlantic coast. The density of the chimes will reflect in the patterns of placement and the force of the wind. The experience will hope to remind the visitor that sugar cane as an object is meaningless; it is the entire surrounding that gives it meaning.

By participation we gain an experiential depth that builds a connectedness to the life and how it is lived within a place. Only then can we respond to history by recognizing the contemporary culture. We can respect the past, and look to the future by living and experiencing the present.

\section{References}

[1] Oxford English Dictionary. nd. http://www.oed.com/ (accessed September 23, 2012).

[2] Loomba, Ania. Colonialism/Postcolonialism. New York: Routledge, 1998.

[3] Said, Edward W. Orientalism. London: Routledge, 1978.

[4] Fanon, Frantz. Black Skin White Masks. New York: Grove Press, 1967.

[5] Hubbard, Vincent K. Swords, Ships \& Sugar: History of Nevis. Corvallis: Premiere Editions International, Inc., 2002.

[6] Eggener, Keith. "Placing Resistance: A Critique of Critical Regionalism." In Architectural Regionalism Collected Writings on Place, Identity, Modernity, and Tradition, by Canizaro Vincent B, 395-411. New York: Princeton Architectural Press, 2002.

[7] Hamilton Harris, Harwell. "Regionalism." In Architectural Regionalism Collected Writings on Place, Identity, Modernity and Tradition, by Vincent B Canizaro, 67-69. New York: Princeton Architectural Press, 1978.

[8] Cassidy, Timothy. "Becoming Regional over Time: Toward a Reflexive Regionalism.” In Architectural Regionalism: Collective Writings on Place, Identity, Modernity, and Tradition, by Canizaro Vincent B, 411-419. New York: Princeton Architectural Press, 2000.

[9] Stagno, Bruno. "Tropicality." In Tropical Architecture: Critical Regionalism in the Age of Globalization, by Lefaivre Liane, Stagno Bruno Tzonis Alexander, 65-92. West Sussex: Wiley-Academy, 2001.

[10] World Tourism Organization. nd. http://www2.unwto.org/ (accessed September 23, 2012).

[11] Henville, Evelyn, interview by Uslick Melissa. Executive Director of the Nevis Conservation and Historical Society (August 2, 2012). 
[12] Nettleford, Rex. "Heritage Tourism and the Myth of Caribbean Paradise." In Tourism Marketing and Management in the Caribbean, by Goodrich Johnathan N Gayle Dennis L, 143-146. New York: Routledge, 1993.

[13] Cummins, Alissandra. "Exhibiting Culture: Museums and National Identity in the Caribbean." Caribbean Quarterly, 1992: 33-53.

[14] Nevis Conservation and Historical society. nd. http://www.nevis-nhcs.org/ nevishistory.html (accessed September 23, 2012).

[15] Cannizzo, Jeanne. "How Sweet it is: Cultural Politics in Barbados." Muse, 1987: 22-26. 